\title{
MIDAZOLAM AS AN ADJUVANT TO BUPIVACAINE IN SUPRACLAVICULAR APPROACH OF BRACHIAL PLEXUS BLOCK
}

\author{
Sakuntala Muniyandi1, Bala Subramani Murugesan², Chithra Devi Ramakrishnan ${ }^{3}$
}

${ }^{1}$ Assistant Professor, Department of Anaesthesiology, Government Theni Medical College, Theni.

${ }^{2}$ Assistant Professor, Department of Anaesthesiology, Government Theni Medical College, Theni.

${ }^{3}$ Assistant Professor, Department of Anaesthesiology, Government Theni Medical College, Theni.

\begin{abstract}
BACKGROUND

Brachial plexus block in supraclavicular approach is a very good postoperative analgesia. Midazolam, a water-soluble benzodiazepine has been used by various routes to prolong analgesia. The analgesic efficacy of midazolam with bupivacaine in brachial plexus block produces significantly faster onset of sensory and motor blockade and prolongs the duration of sensory and motor block and duration of analgesia.

The aim of this study is to compare the effectiveness of addition of midazolam as an adjuvant to bupivacaine in supraclavicular approach of brachial plexus block in upper limb surgery.
\end{abstract}

\section{MATERIALS AND METHODS}

60 patients were recruited to two groups. Group B received $30 \mathrm{~mL}$ of $0.375 \%$ Bupivacaine and Group BM received $30 \mathrm{~mL}$ of $0.375 \%$ Bupivacaine and $50 \mathrm{mcg} / \mathrm{kg}$ of Midazolam.

\section{RESULTS}

On addition of midazolam to bupivacaine, there was significant difference in onset of sensory and motor block compared to bupivacaine. There is prolongation in duration of analgesia, duration of sensory and motor blockade. There is no significant difference in haemodynamics and no side effects like hypotension, bradycardia or respiratory depression.

\section{CONCLUSION}

The addition of midazolam to LA solution in supraclavicular approach to brachial plexus block produces significantly faster onset of sensory and motor blockade and prolongs the duration of sensory and motor block and duration of analgesia.

\section{KEYWORDS}

Supraclavicular, Brachial Plexus Block, Midazolam.

HOW TO CITE THIS ARTICLE: Muniyandi S, Murugesan BS, Ramakrishnan CD. Midazolam as an adjuvant to bupivacaine in supraclavicular approach of brachial plexus block. J. Evolution Med. Dent. Sci. 2017;6(61):4454-4458, DOI: $10.14260 /$ Jemds/2017/963

\begin{abstract}
BACKGROUND
Pain is a fundamental biological phenomenon, always underestimated and undertreated. The relief of pain during surgery is the main part of anaesthesia. In 1911, Kulenkampff introduced the classical approach to brachial plexus block. Winnie and Collins introduced the lateral perivascular approach.

Midazolam is known to produce antinociception and potentiates the effect of local anaesthetic when given in neuraxial block. The effect is produced by its action on GABAA receptors and peripheral nerves containing these receptors. This study was designed to compare the effectiveness of adding midazolam to bupivacaine in supraclavicular approach of brachial plexus block for prolonging the duration of sensory and motor block and duration of analgesia in upper limb surgery.
\end{abstract}

Financial or Other, Competing Interest: None.

Submission 09-02-2017, Peer Review 18-07-2017,

Acceptance 24-07-2017, Published 31-07-2017.

Corresponding Author:

Dr. Bala Subramani Murugesan,

H17/420, Doctors Avenue,

Chatrapatti Road,

Mullai Nagararanmanai Pudur (P. O.),

Theni-625531, Theni District, Tamilnadu.

E-mail: balsanaes@rediffmail.com

DOI: $10.14260 /$ jemds $/ 2017 / 963$

\begin{abstract}
MATERIALS AND METHODS
This study was conducted at Government Rajaji Hospital, attached to Madurai Medical College. After getting approval from the Institution's Ethical Committee and obtaining highrisk informed consent, the study was conducted on 60 patients. Sample size calculation was not done for sake of convenience and this study was non-randomised control study.
\end{abstract}

\section{Inclusion Criteria}

- Age more than 20.

- Both sex.

- ASA Grading I and II.

- Undergoing upper limb surgery.

\section{Exclusion Criteria}

- Patients allergic to local anaesthetic.

- Contraindications to the use of midazolam.

Patients were allocated randomly to two groups, Group B and Group BM. Each group having 30 patients, surgery was done under supraclavicular approach of brachial plexus block.

No premedications were given. IV access was obtained, Anaesthesia machine checked, Resuscitative drugs and 
equipment kept ready. Supraclavicular block was performed by subclavian/lateral perivascular approach by using peripheral nerve locator.

Group B- $30 \mathrm{~mL}$ of $0.375 \%$ Bupivacaine alone.

Group BM- $30 \mathrm{~mL}$ of $0.375 \%$ Bupivacaine with $50 \mathrm{mcg} / \mathrm{kg}$ of midazolam

\section{Parameters Observed}

1. Onset of Sensory Blockade

Abolishment of pain (pin prick) over distribution of ulnar and median nerve assessed every minute after performance of block.

2. Onset of Motor Blockade

Assessed every 2 mins after block using 4-point scale.

- 0 - Normal power.

- 1-Weakness present, but able to move arm.

- 2- Not able to move arm, but able to move fingers.

- 3-Complete motor block.

Attaining a score of 2 was considered as onset of Motor block.

3. Duration of Surgery.

4. Duration of Sensory block.

5. Duration of Motor block.

When 3 in four-point scale changes to 2 , the blockade is said to reverse giving the duration of motor block.

\section{Duration of Analgesia}

The pain was assessed by VAS (Visual Analogue Scale) numbered from 0 - 10.

VAS 0- No pain.

VAS 10- Worst pain.

Pain was observed for every 30 mins after surgery is over, till motor block reverses thereafter hourly for every 6 hrs. and then $2^{\text {nd }}$ hourly for next $6 \mathrm{hrs}$. Duration of Postoperative analgesia is the period of time after surgery till the time when patient needs analgesics (VAS > 5).

\section{Vital Parameters}

Pulse rate, BP and respiratory rate were monitored every 5 mins.

\section{Sedation Score}

Brain and ready scoring was employed,

- 0 - Fully awake.

- 1- Drowsy.

- 2-Drowsy, but arousable on touch or call.

- 3- Drowsy and arousable on deep stimuli.

- 4-Somnolent.

9. Side effects noted are Sedation, Hypotension, Bradycardia.

Patients in whom the block was unsuccessful due to total failure/missed dermatomes/ which needed IV supplementation/ need for GA were excluded from the study.

\section{Statistical Tools}

The information collected regarding all the selected cases were recorded in a Master Chart. Data analysis was done with the help of computer using Epidemiological Information Package (EPI 2010) developed by Centre for Disease Control, Atlanta.

Using this software range, frequencies, percentages, means, standard deviations, chi square and ' $p$ ' values were calculated. Independence ' $\mathrm{T}$ ' test was done and KruskalWallis chi-square test was used to test the significance of difference between quantitative variables and Yate's chisquare test for qualitative variables. A ' $p$ ' value less than 0.05 is taken to denote significant relationship.

\section{RESULTS}

\section{Demographic Data}

\section{Age Distribution}

Patients are categorised into 5 groups, 20 yrs., 21 - 30 yrs., 31 - 40 yrs., 41 - 50 yrs. and above 50 yrs. in both groups which is shown in Table 1.

There is no significant difference in two groups (' $p$ ' value $0.1131)$.

\section{Weight Distribution}

As shown in Table 2 .

There is no significant difference in two groups ( $P$ value 0.0721).

\section{Sex Distribution}

Shown in Table 3, male patients are $63.3 \%$ and females are $36.7 \%$. There is no significant difference in both groups (P value 0.7842 ).

\section{Onset of Sensory Block}

Sensory block was taken within 8 - 10 mts in Group BM and it was within 15 - 19 mts in Group B, which is shown in Table 4. The onset of block was significantly faster in midazolam group ( $\mathrm{p}$ value $<0.0001$ ).

\section{Onset of Motor Block}

Motor block was taken within 13 - $20 \mathrm{mts}$ and 20 - $25 \mathrm{mts}$ in Group BM and Group B respectively, which is shown in Table 5.

The onset of motor block was significantly faster in midazolam group ( $\mathrm{p}$ value $<0.0001$ )

\section{Duration of Surgery}

As shown in Table 6, it was $0.53 \mathrm{hrs}$. in both groups.

Duration of surgery was comparable in both groups ( $p$ value $<0.5511$ ).

\section{Duration of Motor Block}

It was 7 - 9 hrs. and 5 - 7 hrs. respectively in both groups as shown in Table 7.

Duration of Motor block was prolonged significantly in midazolam group ( $\mathrm{p}$ value $<0.0001$ ).

\section{Duration of Sensory Block}

As shown in Table 8, it was 11 - 15 hrs. and 5 - 9 hrs. respectively in both groups.

Duration of sensory blockade was prolonged significantly in midazolam group ( $\mathrm{p}$ value $<0.0001$ ). 


\section{Duration of Analgesia}

It was prolonged in Group BM, which was 15 - $18 \mathrm{hrs}$. which is shown in Table 9.

Duration of analgesia was prolonged significantly in midazolam group ( $\mathrm{p}$ value $<0.0001$ ).

Sedation Score was shown in Table 10.

Midazolam group has significant sedation score than bupivacaine group ( $\mathrm{p}$ value 0.0001 ).

\section{Haemodynamic Changes}

Was shown in Table 11

The ' $p$ ' values are not statistically significant.

There was no significant haemodynamic changes after administration of midazolam and bupivacaine. In both the groups, there was no incidence of side effects like hypotension or bradycardia.

\begin{tabular}{|c|c|c|c|c|}
\hline \multirow{2}{*}{ Age in Yrs. } & \multicolumn{2}{|c|}{ BM Group } & \multicolumn{2}{c|}{ B Group } \\
\cline { 2 - 5 } & No. & $\mathbf{\%}$ & No. & \% \\
\hline Up to 20 yrs. & 4 & 13.3 & 1 & 3.3 \\
\hline 21 - 30 yrs. & 11 & 36.7 & 6 & 20 \\
\hline 31 - 40 yrs. & 7 & 23.3 & 12 & 40 \\
\hline 41 - 50 yrs. & 6 & 20.0 & 5 & 16.7 \\
\hline Above 50 yrs. & 2 & 6.7 & 6 & 20 \\
\hline Total & 30 & 100 & 30 & 100 \\
\hline Range & $15-60$ yrs. & $16-75$ yrs. \\
\hline Mean & \multicolumn{2}{|c|}{33.6 yrs. } & 39.5 yrs. \\
\hline SD 12.4 yrs. & \multicolumn{3}{c|}{0.1131} \\
\hline P value. \\
\hline \multicolumn{3}{|c|}{ Table 1. Age Distribution } \\
\hline
\end{tabular}

\begin{tabular}{|c|c|c|}
\hline Weight (Kg) & Group BM & Group B \\
\hline Range & $45-60$ & $42-60$ \\
\hline Mean & 52.7 & 54.6 \\
\hline S.D & 4.4 & 5.3 \\
\hline P value & \multicolumn{2}{|c|}{0.0721} \\
\hline \multicolumn{2}{|c|}{ Table 2. Weight Distribution } \\
\hline
\end{tabular}

\begin{tabular}{|c|c|c|c|c|}
\hline \multirow{2}{*}{ Sex } & \multicolumn{2}{|c|}{ Group BM } & \multicolumn{2}{c|}{ Group B } \\
\cline { 2 - 5 } & No. & $\mathbf{\%}$ & No. & $\mathbf{\%}$ \\
\hline Male & 21 & 70 & 19 & 63.3 \\
\hline Female & 9 & 30 & 11 & 36.7 \\
\hline Total & $\mathbf{3 0}$ & $\mathbf{1 0 0}$ & $\mathbf{3 0}$ & $\mathbf{1 0 0}$ \\
\hline P value & \multicolumn{3}{|c|}{0.7842} \\
\hline \multicolumn{4}{|c}{ Table 3. Sex Distribution } \\
\hline
\end{tabular}

\begin{tabular}{|c|c|c|}
\hline Onset of Sensory Block & Group BM & Group B \\
\hline Range & $8-10 \mathrm{mins}$ & $15-19 \mathrm{mins}$ \\
\hline Mean & $8 \mathrm{mins}$ & $17.9 \mathrm{mins}$ \\
\hline S.D & $0.8 \mathrm{mins}$ & $0.8 \mathrm{mins}$ \\
\hline P value & \multicolumn{2}{|c|}{0.0001} \\
\hline \multicolumn{2}{|c|}{ Table 4. Onset of Sensory Block } \\
\hline
\end{tabular}

\begin{tabular}{|c|c|c|}
\hline Onset of Motor Block & Group BM & Group B \\
\hline Range & $13-20$ mins & $20-25$ mins \\
\hline Mean & 16.4 mins & $21.8 \mathrm{mins}$ \\
\hline SD & 1.7 mins & $1.5 \mathrm{mins}$ \\
\hline P value & \multicolumn{2}{|c|}{0.0001} \\
\hline \multicolumn{2}{|c|}{ Table 5. Onset of Motor Block } \\
\hline
\end{tabular}

\begin{tabular}{|c|c|c|}
\hline Duration of Surgery (hrs.) & Group BM & Group B \\
\hline Range & $0.5-3 \mathrm{hrs}$. & $0.5-3 \mathrm{hrs}$. \\
\hline Mean & $1.49 \mathrm{hrs}$. & $1.41 \mathrm{hrs}$. \\
\hline S.D & $0.64 \mathrm{hrs}$. & $0.64 \mathrm{hrs}$. \\
\hline P value & \multicolumn{2}{|c|}{0.5511} \\
\hline \multicolumn{2}{|c|}{ Table 6. Duration of Surgery }
\end{tabular}

\begin{tabular}{|c|c|c|}
\hline Duration of Motor Block & Group BM & Group B \\
\hline Range & $7-9 \mathrm{hrs}$. & $5-7 \mathrm{hrs}$. \\
\hline Mean & $7.38 \mathrm{hrs}$. & $6.03 \mathrm{hrs}$. \\
\hline SD & $0.46 \mathrm{hrs}$. & $0.32 \mathrm{hrs}$. \\
\hline P value & \multicolumn{2}{|c|}{0.0001} \\
\hline Table 7. Duration of Motor Block \\
\hline
\end{tabular}

\begin{tabular}{|c|c|c|}
\hline Duration of Sensory Block & Group BM & Group B \\
\hline Range & $11-15 \mathrm{hrs}$. & $5-9 \mathrm{hrs}$. \\
\hline Mean & $13.5 \mathrm{hrs}$. & $8 \mathrm{hrs}$. \\
\hline SD & $2.6 \mathrm{hrs}$. & $0.7 \mathrm{hrs}$. \\
\hline P value & \multicolumn{2}{|c|}{0.0001} \\
\hline Table 8. Duration of Sensory Block \\
\hline \multicolumn{2}{|l}{} \\
\hline
\end{tabular}

\begin{tabular}{|c|c|c|}
\hline Duration of Analgesia (hrs.) & Group BM & Group B \\
\hline Range & $15-18 \mathrm{hrs}$. & $8-16 \mathrm{hrs}$. \\
\hline Mean & $16.8 \mathrm{hrs}$. & $10.1 \mathrm{hrs}$. \\
\hline SD & $0.9 \mathrm{hrs}$. & $1.8 \mathrm{hrs}$. \\
\hline P value & \multicolumn{2}{|c|}{0.0001} \\
\hline Table 9. Duration of Analgesia \\
\hline
\end{tabular}

\begin{tabular}{|c|c|c|}
\hline Sedation Score & Group BM & Group B \\
\hline Range & $1-3$ & $0-1$ \\
\hline Mean & 2.1 & 0.33 \\
\hline SD & 0.48 & 0.28 \\
\hline P value & \multicolumn{2}{|c|}{0.0001} \\
\hline \multicolumn{2}{|c|}{ Table 10. Sedation Score } \\
\hline
\end{tabular}

\begin{tabular}{|c|c|c|c|c|c|c|c|c|}
\hline & Pulse Rate & \multicolumn{2}{c|}{ Systolic BP } & \multicolumn{2}{c|}{ Diastolic BP } & \multicolumn{2}{c|}{ SP02 } \\
\cline { 2 - 9 } & GpBM & GpM & GpBM & GpM & GpBM & GpM & GpBM & GpM \\
\hline Mean & 87.7 & 87.8 & 121.0 & 122 & 70.7 & 71.6 & 98.7 & 98.5 \\
\hline S.D & 6.3 & 4.7 & 5.9 & 4.1 & 5.9 & 4.3 & 0.6 & 0.6 \\
\hline P value & 0.8244 & \multicolumn{1}{|c}{0.8591} & 0.6840 & 0.01724 \\
\hline \multicolumn{10}{|c|}{ Table 11. Haemodynamic Changes } \\
\hline
\end{tabular}

\section{DISCUSSION}

GABA A receptor (GABA A R) is an ionotropic receptor and ligand-gated ion channel. Its endogenous ligand is GammaAminobutyric Acid (GABA), the major inhibitory neurotransmitter in the central nervous system. Upon activation, the GABA receptors selectively conducts chloride through its pores, resulting in hyperpolarisation of the neuron. This causes an inhibitory effect on neurotransmission by diminishing the chance of a successful action potential occurring ligands which contribute to receptor activation typically having anxiolytic, anticonvulsant, amnesic, sedative, hypnotic, euphoriant and muscle relaxant properties. Ligands which decrease receptor activation have opposite effects including anxiogenesis and convulsions. $1,2,3$

Midazolam was synthesised in 1976 by Fryer and Walser. First used in 1986, by Nilsson and colleagues. Midazolam acts on GABA receptors in the spinal cord. When used as an adjuvant with local anaesthetic in intrathecal, epidural and 
caudal blocks, it prolonged the duration of analgesic effect of local anaesthetics. $4,5,6$

By statistical analysis of two groups the age, sex, weight and duration of surgery was comparable in both groups.

\section{Onset of Sensory Block}

Mean onset of sensory block in Group BM was $8.0 \pm 0.8$ mins and in Group B was $17.9 \pm 0.8$. The difference between the two groups was statistically significant with a ' $p$ ' value of $0.0001(\mathrm{p}<0.05)$.

\section{Onset of Motor Block}

Mean onset of motor block in Group BM was $16.4 \pm 1.7$ mins and in Group B it was $21.8 \pm 1.5$ mins. The difference between the two groups was statistically significant with a ' $p$ ' value of $0.0001(\mathrm{p}<0.05)$.

On addition of Midazolam to LA solution, there is difference in onset of sensory and motor block.

Nasreen Laiq et al study also reported similarly that the onset of sensory block was $14 \pm 3.1$ mins, $18.5 \pm 3.5$ mins in Group BM and Group B and motor block of $10.5 \pm 2.4$ mins, $18.5 \pm 3.5$ mins in Group BM and B respectively.7,8,9

\section{Duration of Motor Block}

Mean duration of motor block from score 3 - 3 in Group BM was $7.83 \pm 0.46 \mathrm{hrs}$. and in Group B was $6.03 \pm 0.32 \mathrm{hrs}$. The difference between the two groups was statistically significant with a ' $p$ ' value of $0.0001(\mathrm{p}<0.05)$.

This result correlates with studies conducted by Nasreen et al. In Midazolam group it was $7.65 \pm 3.20 \mathrm{hrs}$. compared to bupivacaine group it was $5.20 \pm 2.10 \mathrm{hrs}$.

\section{Duration of Sensory Block}

The mean duration of sensory block in Group BM was $13.5 \pm$ $2.6 \mathrm{hrs}$. and in Group B was $8.0 \pm 0.7 \mathrm{hrs}$. The difference between the two groups was statistically significant with a ' $p$ ' value of $0.0001(\mathrm{p}<0.05)$.

This is comparable with study done by Koj Jarbo, Yatindra Kumar Batra et al in which the duration of sensory block was $7 \pm 4.32 \mathrm{hrs}$. in midazolam group compared to $5.95 \pm 1.4 \mathrm{hrs}$. in plain bupivacaine group. ${ }^{10,11,12}$

\section{Duration of Analgesia}

The mean duration of analgesia is till VAS score $>5$ and in Group BM it was $16.8 \pm 0.9 \mathrm{hrs}$. and in Group B it was $10.1 \pm$ 0.9 hrs. The difference between the two groups was statistically significant with a 'p' value of $0.0001(\mathrm{p}<0.05)$.

These results correlate favourably with studies conducted by Nasreen Laiq et al. The mean duration of complete analgesia was significantly prolonged $(p=0.002)$ in the bupivacaine-midazolam group.

\section{Sedation Score}

The sedation score in Group BM was $2.1 \pm 0.48$, and in Group $B$ was $0.33 \pm 0.28$. In midazolam group since the sedation score was not more than 3 , the respiratory function was not compromised. So, intraoperative sedation is well observed in midazolam group.

\section{Haemodynamics}

In this study, no significant difference was observed with respect to pulse rate, systolic and diastolic blood pressure and SPO2. This finding is consistent with the observations made by Nasreen Laiq et al, who concluded that there were no significant haemodynamic changes after administration of midazolam with bupivacaine.

\section{Side Effects}

Patients were observed for the side effects such as sedation, hypotension and bradycardia. No complications related to brachial plexus block were observed.

Gulec et al reported that bupivacaine-midazolam prolonged postoperative analgesia compared to bupivacainemorphine combination when given caudally.

Tucker and Associates reported the analgesic effects of intrathecal midazolam in combination with intrathecal fentanyl in labouring patients. ${ }^{13,14,15}$

In this study, the addition of midazolam to local anaesthetic solution produce difference between the onset of sensory and motor blockade when compared to bupivacaine group.

The duration of analgesia is significantly higher in midazolam group when compared to bupivacaine group.

The duration of sensory blockade is also increased in midazolam group. These inferences provide midazolam producing a prolonged sensory and motor blockade.

\section{CONCLUSION}

The addition of Midazolam to Local anaesthetic solution in supraclavicular approach to brachial plexus-

- Produces significantly faster onset of sensory and motor block.

- Prolongs the duration of sensory and motor block and duration of analgesia.

\section{REFERENCES}

[1] Winnie AP, Tay CH, Patel KP, et al. Pharmacokinetics of local anesthetics during plexus blocks. Anaesth Analg 1977;56(6):852-61.

[2] Moore DC, Bridenbaugh LD, Thompson GE, et al. Bupivacaine: a review of 11,080 cases. Anesth Analg 1978;57(1):42-53.

[3] Suman C, Mitra LG, Biswas BN, et al. Tramadol as an adjuvant for brachial plexus block. J Anaesth Clin pharmacol 2007;23(2):187-9.

[4] Robaux S, Blunt C, Viel E, et al. Tramadol added to $1.5 \%$ mepivacaine for axillary brachial plexus block improves post-operative analgesia dose dependently. Anaesth Analgesia 2004;98(4):1172-7.

[5] Hutschala D, Mascher H, Schmetterer L, et al. Clonidine added to bupivacaine enhances and prolongs analgesia after brachial plexus block via a local mechanism in healthy volunteers. Eur J Anaesthesiol 2004;21(3):198-204.

[6] Azimaraghi O, Marashi SM, Khazaei N, et al. The effect of adding sufentanil to $0.5 \%$ hyperbaric bupivacaine on duration of brachial plexus blockade in chronic opium abusers: a randomized clinical trial. Anaesth Pain Med 2015;5(3):e21960. 
[7] Jarbo K, Batra YK, Panda NB. Brachial plexus block with midazolam and bupivacaine improves analgesia. Can J Anaesth 2005;52(8):822-6.

[8] Shrestha BR, Maharjan SK, Tabedar S. Supraclavicular brachial plexus block with and without dexamethasone- a comparative study. Kathmandu Univ Med J (KUMJ) 2003;1(3):158-60.

[9] Persec J, Persec Z, Kopljar M, et al. Low-dose dexamethasone with levobupivacaine improves analgesia after supraclavicular brachial plexus blockade. International Orthopaedics 2014;38(1):101-5.

[10] Shrestha BR, Maharjan SK, Shrestha S, et al. Comparative study between tramadol and dexamethasone as an admixture to bupivacaine in supraclavicular brachial plexus block. JNMA J Nepal Med Assoc 2007;46(168):158-64.

[11] Islam SM, Hossain MHMD, Maruf AA. Effect of addition of dexamethasone to local anaesthetics in supraclavicular brachial plexus block. JAFMC Bangladesh 2011;7(1):11-4.
[12] Biradar PA, Kaimar P, Gopalakrishna K. Effect of dexamethasone added to lidocaine in supraclavicular brachial plexus block: a prospective, randomised, double-blind study. Indian J Anaesth 2013;57(2):1804.

[13] Dar FA, Najar MR, Jan N. Effect of addition of dexamethasone to ropivacaine in supraclavicular brachial plexus block. Indian Journal of Pain 2013;27(3):165-9.

[14] Movafegh A, Razazian M, Hajimaohamadi F, et al. Dexamethasone added to lidocaine prolongs axillary brachial plexus blockade. Anaesth Analg 2006;102(1):263-7.

[15] Tandoc MN, Fan L, Kolesnikov S, et al. Adjuvant dexamethasone with bupivacaine prolongs the duration of interscalene block: a prospective randomized trial. J Anaesth 2011;25(5):704-9. 